\title{
İtalyan çimi tarımının mekanizasyon özelliklerinin ve enerji verimliliğinin belirlenmesi
}

\section{Determination of mechanization properties and energy efficiency of Italian grass agriculture}

\author{
Ergün ÇITIL ${ }^{1 *}$ iD , Tamer MARAKOĞLU ${ }^{1}$ iD Hasan KIRILMAZ $^{1}$ iD, Kazım ÇARMAN $^{1}$ \\ ${ }^{1}$ Selçuk Üniversitesi, Ziraat Fakültesi, Tarım Makineneleri ve Teknolojileri Mühendisliği, Konya
}

\section{To cite this article:}

Çıtıl, E., Marakoğlu, T., Kırılmaz, H. \& Çarman, K. (2020). İtalyan çimi tarımının mekanizasyon özelliklerinin ve enerji verimliliğinin belirlenmesi. Harran Tarım ve Gıda Bilimleri Dergisi, 24(3): 336-346.

DOI:10.29050/harranziraat. 702848

\author{
Address for Correspondence: \\ Ergün ÇITIL \\ e-mail: \\ ecitil@selcuk.edu.tr
}

Received Date:

16.03.2020

Accepted Date:

07.07.2020

(C) Copyright 2018 by Harran University Faculty of Agriculture. Available on-line at www.dergipark.gov.tr/harranziraat
Öz

Günümüzde yem bitkileri üretim alanlarının artırabilmesi için mevcut yem bitkileri çeşitliliğinin artırılması ve ekim nöbetinde kullanılmaları zorunludur. Bu alanlarda ekolojik şartların elverdiği ölçüde ekonomik üretim modelini geliştirmek gerekmektedir. Bu çalışma 2018 yılında, Konya Selçuk Üniversitesi Ziraat Fakültesi Sarıcalar Uygulama ve Araştırma Çiftliğinde yem bitkilerinin çeşitliliğinin artırılması amacı ile yürütülmüştür. Çalışmada; İtalyan çiminin mekanizasyon özelliklerinin ve enerji verimliliğinin belirlenmesi amaçlanmıştır. Üretiminde kullanılan makine ve ekipmanların yakıt tüketimleri, toplam enerji girdi ve çıktıları ile enerji verimliliği hesaplanmıştır.

Araştırma sonuçlarına göre; En fazla yakıt tüketimi hasat grubu makinelerde 43.2 I ha-1 ile balya makinesinde, toprak işleme grubu makinelerinde ise $17.2 \mathrm{I} \mathrm{ha}{ }^{-1}$ ile pullukla çalışmada tespit edilmiştir. Toplam enerji çıktısı $81572.40 \mathrm{MJ} \mathrm{ha}^{-1}$ ve toplam enerji girdisi $34197.97 \mathrm{MJ}$ $\mathrm{ha}^{-1}$ olarak hesaplanmış ve bunlara bağlı olarak net enerji verimliliği $47374.43 \mathrm{MJ} \mathrm{ha}^{-1}$, enerji oranı 2.39 ve enerji verimliliğide $0.14 \mathrm{~kg} \mathrm{MJ}^{-1}$ olarak bulunmuştur. Özgül enerji olarak tanımlanan bir kg ürünün elde edilmesi için gerekli enerji miktarıda $7.31 \mathrm{MJ} \mathrm{kg}^{-1}$, Net enerji veriminin toplam enerji girdisine oranını ifade eden net enerji oranıda 0.58 olarak hesaplanmıştır. Enerji girdileri içinde doğrudan enerji \%45.62, dolaylı enerji \%54.38 yenilenemeyen enerji \%65.38 ve yenilenebilir enerji ise \%34.62 paya sahip olduğu tespit edilmiştir.

Anahtar Kelimeler: İtalyan çimi, Doğrudan enerji, Dolaylı enerji, Yenilenebilir enerji, Yenilenemeyen enerji

\section{ABSTRACT}

Today, forage crops and crop rotation is mandatory for use in enhancing the diversity of available forage crops to increase production. In these areas, it is necessary to develop the economic production model as far as ecological conditions allow. This study was carried out in 2018 at Konya Selcuk University Faculty of Agriculture Saricalar Application and Research Farm to increase the diversity of forage crops. Study; It is aimed to determine the mechanization properties and energy efficiency of Italian grass. Fuel consumption, total energy inputs and outputs and energy efficiency of the machinery and equipment used in its production are calculated.

According to the research results; the highest fuel consumption was determined in the baler machine with $43.2 \mathrm{I} \mathrm{ha}^{-1}$ in the harvest group machines and with the plow with $17.2 \mathrm{I} \mathrm{ha} \mathrm{a}^{-1}$ in the soil processing group machines. Total energy output is calculated as $81572.40 \mathrm{MJ}^{-1}$ and total energy input is $34197.97 \mathrm{MJ} \mathrm{ha}^{-1}$ and accordingly, net energy efficiency is 47374.43 $\mathrm{MJ} \mathrm{ha}{ }^{-1}$, energy ratio is 2.39 and energy efficiency is $0.14 \mathrm{~kg} \mathrm{MJ}^{-1}$ was found. The amount of energy required to obtain a kg product defined as specific energy was calculated as $7.31 \mathrm{MJ}$ $\mathrm{kg}^{-1}$, and the net energy ratio, which represents the ratio of net energy efficiency to total energy input, was calculated as $0.58 \mathrm{It}$ is determined that direct energy has $45.62 \%$, indirect energy $54.38 \%$ non-renewable energy $65.38 \%$ and renewable energy $34.62 \%$.

Key Words: Italian grass, Direct energy, Indirect energy, Renewable energy, Nonrenewable energy 
Giriş

Dünya da birçok ülkede İnsanların yeterli ve dengeli beslenmesi genel bir problemdir. Sınırlı doğal kaynaklardan, sürdürülebilirlik ilkesine bağlı kalmak şartıyla, en yüksek seviyede faydalanarak hızla çoğalmakta olan nüfusun yeterli ve dengeli beslenmesini sağlamak gerekmektedir. (Anonymous, 2008).

Sürdürülebilir tarımın temel şartlarından biri enerjinin verimli kullanılmasıdır. Tarımsal faaliyetlerde enerji kullanımı artış göstermektedir. Artan nüfus ve yüksek yaşam standartları için, ekilebilir alanların sınırlı olması, her daim artış gösteren gıda tüketimi; kimyasal gübrelerin, zirai ilaçların, tarım makinelerinin ve diğer doğal kaynakların yoğun şekilde tarımsal üretimlerde kullanılmasına sebeb olmuştur. Yoğun enerji kullanımı insan sağı̆̆ını ve doğal yaşam alanlarını tehdit eden sorunlara neden olmaktadır. Tarımsal üretimde enerjinin verimli kullanılması, çevre sorunlarını minimize edecek, doğal kaynakların zarar görmesini önleyecek ve ekonomik bir üretim sistemi olarak sürdürülebilir tarımı teşvik edecektir. (Erdal ve ark., 2007 )

Tarımsal üretimsde önemi azımsanmayacak bir yere sahip olan yem bitkileri üretimi, bitkisel ve hayvansal üretimin sigortası durumundadır. Tarımsal alanlarda üretimi yapılan otlar hayvanlar tarafından tüketilmekte et, süt vb. ürünlere dönüştürülmesi sağlanarak insanların tüketmesi için kullanılmaktadır. (Soya ve ark., 2004).

Kaliteli kaba yemlerin hayvan beslemede kullanılması, hayvanların performansını iyileştirmesi, besleme kaynaklı birçok metabolik hastalığın önüne geçilmesi ve kalitesi yüksek hayvansal ürün elde edilmesi açısından önemlidir (Alçiçek ve ark., 1988; Alçiçek ve ark., 1999; Alçiçek, 2002).

Hayvan kapasitesi bakımından önemli bir yerde olmamıza rağmen, birim hayvanlardan elde edilen verim olması gerekenden düşüktür. Ülkemizdeki mevcut hayvanlar genel anlamda genetik kapasitesi yüksek hayvanlar olmasına rağmen, ana proplem, hayvanların kalitesi yüksek yemlerle beslenmelerinin yetersiz olmasından kaynaklanmaktadır. Bu nedenle ülkemizdeki hayvanların yeteri kadar kaliteli kaba yemlerle beslenememelerinden dolayı, genetik kapasitelerinin daha çok altında verim alınmaktadır (Karayiğit, 2005).

İtalyan çimi silajının ve kuru otunun yem değerlerine yönelik yapılan bir çalışmalarda; besin madde içerikleri yönünden aralarında herhangi bir fark bulunmadığı, fakat silajın kuru madde sindiriminin (\%77) kuru otunkinden (\%73) daha fazla olduğu (Ohshima ve ark, 1988) tespit edilmiştir.

İtalyan çiminini biçildikten sonra balya silajı ve haylaj şeklinde silolamanın benzer değerlere sahip olduğunu, yemden faydalanma yönünden balya silajının kuru ota göre daha iyi olduğu, italyan çimi kuru ot olarak saklanmasında protein ve enerji açısından düşük değerler verdiği belirlenmiştir (Mc Cormick ve ark., 1998).

Son yıllarda Ülkemizde iklim ve toprak koşulları uygun olan Marmara, Ege ve Akdeniz bölgeleri başta olmak üzere İtalyan çimi Caramba çeşidi yetiştirilmeye başlanmıştır. Çoğunlukla ruminantlara biçildikten sonra taze olarak verilen ya da otlatılarak yedirilen İtalyan çimi Caramba çeşidi, kuru ot veya silaj olarakda kullanılmaktadır (Özkul ve ark. 2012). Caramba, olması gereken sıcaklık değerlerinde ekimi yapıldığında 25-35 günde ilk biçim yapılabilmektedir. Yılda 6 biçim yapılabildiği açıklansada (Lenuweit ve Gharadjedaghi, 2002), en fazla kuru ot veriminin yılda 2 biçim yapıldığında alındığı belirlenmiştir. (Kesiktaş, 2010).

Schota ve Weıhıng (1951), İtalyan çimi'nin kış mevsimlerini çok soğuk geçiren bölgelerde ilkbahar aylarında kışı ılıman geçen bölgelerde ise sonbahar aylarında ekilmesinin uygun olduğunu, fakat serin ve yağışlı iklim özelliği gösteren bölgelerde baharda yapılacak ekimlerin mümkün olduğu kadar erken yapılmasının gerektiği ifade edilmiştir.

Normal şartlarda bir biçimde dekardan yeşil ot verimi $1500-2500 \mathrm{~kg}$, kuru ot verimi ise $500-800$ $\mathrm{kg}$ arasında elde edilebilmektedir. Sulu tarım yapılan ya da yeterli yağış alan bölgelerde 2-3 biçim alınarak $4000-6000 \mathrm{~kg} \mathrm{da}^{-1}$ yeşil ot verimi, 750-1500 $\mathrm{kg} \mathrm{da}^{-1}$ arasında kuru ot verimi elde edilmektedir. Ülkemizde son yıllarda yem 
bitkilerine verilen teşviklerle İtalyan çimi bölgesinde 1243.23 kg da-1; Darvıshı (2009), yetiştiriciliği, benimsenmeye başlanmıştır. (Baytekin ve ark., 2009)

Kuşvuran ve Tansı (2005), Çukurova bölgesi koşullarında Caramba otunun verimi üzerine yaptıkları çalışmada, yeşil ot ve kuru ot verimlerinin sırasıyla $3102 \mathrm{~kg} \mathrm{da}^{-1}$ ve $695 \mathrm{~kg} \mathrm{da}^{-1}$ olduğunu bildirmişlerdir.

Serin ve ark. (1996)'nın Erzurum'da $822 \mathrm{~kg} \mathrm{da}^{-1}$; Açıkgöz (2001), 1250-2000 kg da-1; Kuşvuran ve Tansı (2004), Çukurova bölgesinde 1187.09 Ankara bölgesinde $1643.2 \mathrm{~kg} \mathrm{da}^{-1}$; Kesiktaş (2010), Karaman bölgesinde $737.8 \mathrm{~kg} \mathrm{da}^{-1}$ ve Kuşvuran ve ark.(2014) Çankırı bölgesinde yapmış oldukları araştırma neticesinde $630 \mathrm{~kg} \mathrm{da}^{-1} \mathrm{kuru}$ ot verimi aldıklarını belirtmişlerdir.

Türkiye'nin yıllara göre büyükbaş ve küçükbaş hayvan sayıları ile Türkiye'nin yıllara göre İtalyan Çimi ekim alanı ve üretim miktarındaki değişim Çizelge 1 ve 2'de verilmiştir (Anonim, 2020a; Anonim, 2020b).

$1493.21 \mathrm{~kg} \mathrm{da}{ }^{-1}$; Parlak (2005), yine Çukurova

Çizelge 1. 2018 Türkiye'nin yıllara göre büyükbaş ve küçükbaş hayvan sayıları (Anonim, 2020a)

Table 1. Number of cattle and sheep in 2018, according to Turkey's year (Anonim, 2020a)

\begin{tabular}{lcccc}
\hline $\begin{array}{l}\text { Yıllar } \\
\text { Years }\end{array}$ & $\begin{array}{c}\text { Sığır } \\
\text { Beef }\end{array}$ & $\begin{array}{c}\text { Koyun } \\
\text { Sheep }\end{array}$ & $\begin{array}{c}\text { Keçi } \\
\text { Goat }\end{array}$ & $\begin{array}{c}\text { Toplam } \\
\text { Total }\end{array}$ \\
\hline 2014 & 14223109 & 31140244 & 10344936 & 55708289 \\
2015 & 13994071 & 31507934 & 10416166 & 55918171 \\
2016 & 14080155 & 30983933 & 10345299 & 55409387 \\
2017 & 15943586 & 33677636 & 10634672 & 60255894 \\
2018 & 17042506 & 35194972 & 10922427 & 63159905 \\
2019 & 17688139 & 37276050 & 11205429 & 66169618 \\
\hline
\end{tabular}

Çizelge 2. Türkiye'nin yıllara göre İtalyan Çimi ekim alanı ve üretim miktarındaki değişim (Anonim, 2020b)

Table 2. Changes in Italian Ryegrass planting area and production quantities of the year, according to Turkey (Anonim, 2020b)

\begin{tabular}{lcc} 
& \multicolumn{2}{c}{$\begin{array}{c}\text { Italyan çimi } \\
\text { Italian grass }\end{array}$} \\
\cline { 2 - 3 } Years & $\begin{array}{c}\text { Ekim alanı (da) } \\
\text { Planting area(de) }\end{array}$ & $\begin{array}{c}\text { Yeşil Ot (ton) } \\
\text { Green herb (Tonne) }\end{array}$ \\
\hline 2014 & 4832 & 17023 \\
2015 & 15196 & 58046 \\
2016 & 48001 & 210935 \\
2017 & 77268 & 348046 \\
2018 & 103410 & 448086 \\
2019 & 164452 & 616709 \\
\hline
\end{tabular}

Ülkemizdeki büyükbaş ve küçükbaş hayvan sayısı her yıl artmakta, çayır ve mera alanlarımız ise 2001 yılından beri 14,617.000 ha olarak hiç değişmemiştir.

Özellikle ruminantların beslenmesinde kullanılan ucuz yem kaynaklarının var olması ve bu kaynakların en verimli bir şekilde kullanılmasının sağlanması çok önemlidir. Çünkü hayvansal üretimlerde girdiler içinde yem girdileri \% 60-70 gibi önemli bir oranı teşkil etmektedir. Ülkemizdeki mevcut kaba yem açı̆̆ının giderilmesi için öncelikle çayır- mera alanlarının ıslah edilmesi sağlanmalı, yem bitkileri ekiminin mevcut ekim alanları içindeki payının artırılması ile mümkündür (Anonim, 1998).

Yonca bitkisinin en yüksek verimi üçüncü yılda elde edilmektedir ve daha sonra verim düşüş görülmektedir. Bu nedenle yonca, ekim nöbetinde en az 3 yıl kalmalı, Ot verimi ise; toprağın verimine, gübrelemeye ve sulamaya göre değişim göstermektedir. Her biçimden alınan verim dekara ortalama 1 - 3 ton yeşil ot olarak alınmakta ve bunun kuru ot karşılığı 300 - 800 kg arasında değişmektedir (Anonim, 2020c).

Yem bitkileri tarımının gelişmesi hem alan hem de üretim artışı ile gerçekleşir. $\mathrm{Bu}$ nedenle öncelikle mevcut tarla arazisi içindeki yem bitkileri ekim alanları arttırılmalıdır. Güneydoğu Anadolu Bölgesi illerinde toplam nadas alanı bölgenin ekilebilen toplam arazi varlığının \%10.48'idir. Nadas uygulamasının yapıldığı yerlerde, mutlaka uygun yem bitkileri ekim nöbetine alınarak yem bitkisi yetiştirilmelidir. Ayrıca mevcut yem bitkileri ekim alanlarında bilimsel yetiştirme teknikleri kullanılarak verimlilik arttırılmalıdır. (Sayar ve ark, 2010)

Türkiyede mevcut hayvan varlığı dikkate alındığında 83.9 milyon ton kaba yeme intiyacımız olduğu hesaplanmıştır. Çayır ve mera alanlarından 
yem bitkileri ve silajdan bitkisel üretim artıkları ve diğer kaynaklardan 53.7 milyon ton civarında kaba yem üretimi yapıldığı tahmin edilmektedir. Buna göre 30.2 milyon tonun üzerinde bir kaba yeme ihtiyaç vardır. Bu yem ihtiyacı dikkate alındığında gelişmiş ülkelerde olduğu gibi Türkiye'de de tarla tarımı içerisinde yem bitkileri ekim alanlarını genişletmek ve çeşitlendirmek gereklidir (Özkan ve Demirbağ, 2016). Bu çalışmada Türkiye'de yem bitkileri alanının genişletilmesine ve yeni bir tek yıllık bir yem bitkisi çeşidi olan İtalyan çiminin yetiştiriciliği için mekanizasyon özelliklerinin ve enerji verimliliğinin belirlenmesi amaçlanmıştır.

\section{Materyal ve Metod}

Denemeler Konya Selçuk Üniversitesi Ziraat Fakültesi Sarıcalar Uygulama ve Araştırma Çiftliğinde yürütülmüştür. Çalışmada İtalyan çimi tohumu kullanılmıştır. Ekim: 08.03.2018; Hasat: 1. biçim: 12.06.2018 - 2.biçim: 20.07.2018- 3.Biçim: 05.09.2018 tarihlerinde yapılmıştır. Toprak özelliklerini belirlenmesiamacıyla araştırmanın yapıldığı deneme alanından 0-20 cm derinlikten toprak numuneleri alınarak Selçuk Üniversitesi Ziraat Fakültesi Toprak Bilimi ve Bitki Besleme Bölümü laboratuvarında analizleri yaptırılmıştır. Killi-tınlı toprak tekstürüne sahip olan deneme alanının nem içeriği ortalama \% 42.7 bulunmuştur. Deneme alanına ait toprağın bazı fiziko-mekanik özellikleri Çizelge 3'te verilmiştir.

Çizelge 3. Deneme alanına ait toprağın bazı özellikleri Table 3. Some features of soil belonging to the trial area Toprak Özellikleri

Soil Properties

\begin{tabular}{|c|c|}
\hline $\begin{array}{l}\text { Toprak sınıfı(Tekstür) } \\
\text { Soil class (Texture) }\end{array}$ & Killi-tınlı \\
\hline $\mathrm{pH} 1 / 1$ & 7.90 \\
\hline $\begin{array}{l}\text { Organik Madde (\%) } \\
\text { Organic Matter (\%) }\end{array}$ & 3.00 \\
\hline $\begin{array}{l}\text { Toplam N (\%) } \\
\text { Total N (\%) }\end{array}$ & 31.60 \\
\hline $\begin{array}{l}\text { Kireç (\%) } \\
\text { Lime (\%) }\end{array}$ & 11.00 \\
\hline Penetrasyon Direnci $(\mathrm{MPa})(0-20 \mathrm{~cm})$ & \\
\hline $\begin{array}{l}\text { Penetration Resistance ( } \mathrm{MPa})(0-20 \\
\mathrm{cm})\end{array}$ & 1.15 \\
\hline $\begin{array}{l}\text { Kayma Gerilmesi }\left(\mathrm{N} \mathrm{cm}^{-2}\right) \\
\text { Shear Stress }\left(\mathrm{N} / \mathrm{cm}^{-2}\right)\end{array}$ & 1.20 \\
\hline $\begin{array}{l}\text { Yüzey Profil Düzgünsüzlüğü (\%) } \\
\text { Surface Profile Unevenness (\%) }\end{array}$ & 12 \\
\hline
\end{tabular}

Araştırmanın yapıldığı 2018 yılına ait iklim verileri Meteoroloji Genel Müdürlüğünden alınmış ve alınan ölçüm verileri Çizelge 4. 'de verilmiştir.

Çizelge 4. Denemelere ait vejetasyon süresince alınan meteorolojik veriler

Table 4. Meteorological data obtained during the vegetation of the trials

\begin{tabular}{lcccc}
\hline \multirow{2}{*}{$\begin{array}{l}\text { Aylar } \\
\text { Months }\end{array}$} & \multicolumn{3}{c}{$\begin{array}{c}\text { Sıcaklık }\left({ }^{\circ} \mathrm{C}\right) \\
\text { Temperature }\left({ }^{\circ} \mathrm{C}\right)\end{array}$} & $\begin{array}{c}\text { Yağış }(\mathrm{mm}) \\
\text { Rains }(\mathrm{mm})\end{array}$ \\
\cline { 2 - 4 } & Min. & Max. & $\begin{array}{c}\text { Ortalama } \\
\text { Average }\end{array}$ & \\
\hline $\begin{array}{l}\text { Mart } \\
\text { March }\end{array}$ & 5.0 & 25.0 & 15.0 & 38.0 \\
$\begin{array}{l}\text { Nisan } \\
\text { April }\end{array}$ & 11.0 & 26.0 & 18.5 & 9.0 \\
$\begin{array}{l}\text { Mayıs } \\
\text { May } \\
\text { Haziran }\end{array}$ & 10.3 & 27.3 & 18.2 & 41.0 \\
$\begin{array}{l}\text { June } \\
\text { Temmuz } \\
\text { July }\end{array}$ & 10.4 & 35.6 & 24.9 & 3.6 \\
$\begin{array}{l}\text { Ağustos } \\
\text { August }\end{array}$ & 10.7 & 35.6 & 24.3 & 2.0 \\
$\begin{array}{l}\text { Eylül } \\
\text { September }\end{array}$ & 5.3 & 33.8 & 20.0 & 7.2 \\
\hline $\begin{array}{l}\text { Toplam } \\
\text { Total }\end{array}$ & & 34.1 & 21.0 & 16.6 \\
\hline
\end{tabular}

Çizelgeden görüldüğü üzere deneme alanının bulunduğu Sarıcalar Araştırma ve Uygulama Çiftliğinin İtalyan çiminin ekildiği tarihten itibaren ve en son hasadının yapıldığı tarihler arasındaki toplam yağış miktarı $117.4 \mathrm{~mm}$ ve ortalama hava sıcaklığı 20.2 oC 'dir.

Denemelerde, 2011 üretimi New Holland TD90 D marka 90 BG gücünde dört tekerleği muharrik traktör kullanılmıştır.

İtalya çimi mekanizasyonunda kullanılan makine ve ekipmanların bazı teknik özellikleri Çizelge 5'de verilmiştir.

Denemelerde 24 sıralı ekici sistemi oluklu makara tipine sahip kombine hububat ekim makinesi kullanılmış ve dekara $5 \mathrm{~kg}$ ekim normunu sağlayacak şekilde makine ayarlanmıştır.

Makinelerle çalışma sırasında traktör yakıt tüketiminin belirlenmek için Rudolf Schmitt marka ve \% 0.5 doğruluk oranına sahip ölçüm yapan yakıt ölçüm cihazı kullanılmıştır. İtalyan çimi ekim ile birlikte dekara $20 \mathrm{~kg} \mathrm{da}^{-1}$ DAP ve çıkış tamamlandıktan sonra üst gübresi olarak $25 \mathrm{~kg} \mathrm{da}^{-1}$ ÜRE gübresi verilmiştir. Ayrıca ilk ve ikinci biçimden sonra da dekara 10 kg ÜRE gübresi verilmiştir. 
Çizelge 5. Denemede kullanılan makine ve ekipmanlara ait bazı teknik özellikler Table 5. Some technical features of the machinery and equipment used in the trial

\begin{tabular}{|c|c|c|c|c|c|c|}
\hline $\begin{array}{l}\text { Makine } \\
\text { Machine }\end{array}$ & $\begin{array}{l}\text { Ayak/ Gövde } \\
\text { sayısı } \\
\text { Number of } \\
\text { Foot / Body }\end{array}$ & $\begin{array}{l}\text { İş genişliği } \\
\text { (cm) } \\
\text { Work width } \\
\text { (cm) }\end{array}$ & $\begin{array}{l}\text { İş derinliği } \\
\text { (cm) } \\
\text { Work depth } \\
\text { (cm) }\end{array}$ & $\begin{array}{l}\text { Çalışma hızı } \\
\left(\mathrm{km} \mathrm{h}^{-1}\right) \\
\text { Working } \\
\text { speed }\left(\mathrm{km} \mathrm{h}^{-1}\right)\end{array}$ & $\begin{array}{l}\text { Ağırlık } \\
\text { (Kg) } \\
\text { Weight } \\
(\mathrm{Kg})\end{array}$ & $\begin{array}{l}\text { İş başarısı } \\
\left(\text { ha } \mathrm{h}^{-1}\right) \\
\text { Work Success } \\
\left(\text { ha h }^{-1}\right)\end{array}$ \\
\hline $\begin{array}{l}\text { Pulluk } \\
\text { Plow }\end{array}$ & 5 & 165 & 28 & 4,8 & 647 & 0.63 \\
\hline $\begin{array}{l}\text { Düşey milli freze } \\
\text { Vertical Rotator }\end{array}$ & 10 & 290 & 18 & 4.23 & 1110 & 0.98 \\
\hline $\begin{array}{l}\text { Kültivatör+döner tırmık } \\
\text { Cultivator + Rotary Rake }\end{array}$ & 13 & 330 & 15 & 6.50 & 565 & 1.72 \\
\hline $\begin{array}{l}\text { Ekim makinesi +Merdane } \\
\text { Sowing machine + Roller }\end{array}$ & 24 & 340 & 1 & 7.50 & 1790 & 1.91 \\
\hline $\begin{array}{l}\text { Mineral gübre dağıtma } \\
\text { makinesi } \\
\text { Mineral fertilizer spreading } \\
\text { machine }\end{array}$ & 1 & 1200 & - & 8 & 140 & 7.20 \\
\hline $\begin{array}{l}\text { Diskli çayır biçme makinesi } \\
\text { (Koşullandırıcılı) } \\
\text { Disc mower (with } \\
\text { conditioner) }\end{array}$ & 6 & 240 & & 7 & 750 & 1.43 \\
\hline $\begin{array}{l}\text { Ot toplama tırmı ̆̆ } \\
\text { Weed harrow }\end{array}$ & 4 & 285 & & 10 & 150 & 2.42 \\
\hline $\begin{array}{l}\text { Balya makinesi (balya } \mathrm{h}^{-1} \text { ) } \\
\text { Baler (baler } h^{-1} \text { ) }\end{array}$ & & 160 & & 5.7 & 2460 & 250 \\
\hline
\end{tabular}

Enerji Girdi Çıktı Hesaplamaları: Tohum enerji girdisi, gübre enerji girdisi, yakıt-yağ enerji girdisi ve insan gücü enerji girdisinin birim alan başına kullanılan veya tüketilen girdi miktarları ile bu girdi çeşitlerinin enerji eş değeri ile çarparak hesaplanmıştır. İtalyan çimi tohumu ve biokütlesinin enerji eşdeğerini tespit etmek amacıyla Selçuk Üniversitesi Ziraat Fakültesi Tarım Makineleri ve Teknolojileri Mühendisliği Bölümüne ait biyodizel laboratuvarında analizler yapılmıştır. IKA marka, EN 61010, EN 50082, EN 55014 ve EN 60555 standartlarına göre ölçüm yapabilen kalorimetre cihazı kullanılmıştır. Yapılan ölçümler sonucunda İtalyan çimi tohumu ve biyokütlesinin enerji eşdeğeri belirlenmiş ve Çizelge $6^{\prime}$ da verilmiştir.

Makine enerji girdisinin hesplamaları aşağıda verilen formüle göre yapılmıştır.(Yaldız et al., 1990).

$M E=\frac{A \times K}{T \times C}$

Burada;

ME : Makine enerji girdisi ( $\mathrm{MJ} \mathrm{ha}^{-1}$ ),

A : Makinenin özgül ağırlığı $(\mathrm{kg})$,

$\mathrm{K}$ : Tarım makinesine ait üretim enerjisi $\left(\mathrm{MJ} \mathrm{kg}^{-1}\right)$,

$\mathrm{T}$ : Makinenin ekonomik ömrü (h),

$C$ : Efektif alan iş başarısı $\left(\text { ha } \mathrm{h}^{-1}\right)^{\prime}$ 'dir.
Çizelge 6. Enerji eşdeğerleri

Table 6. Energy equivalents

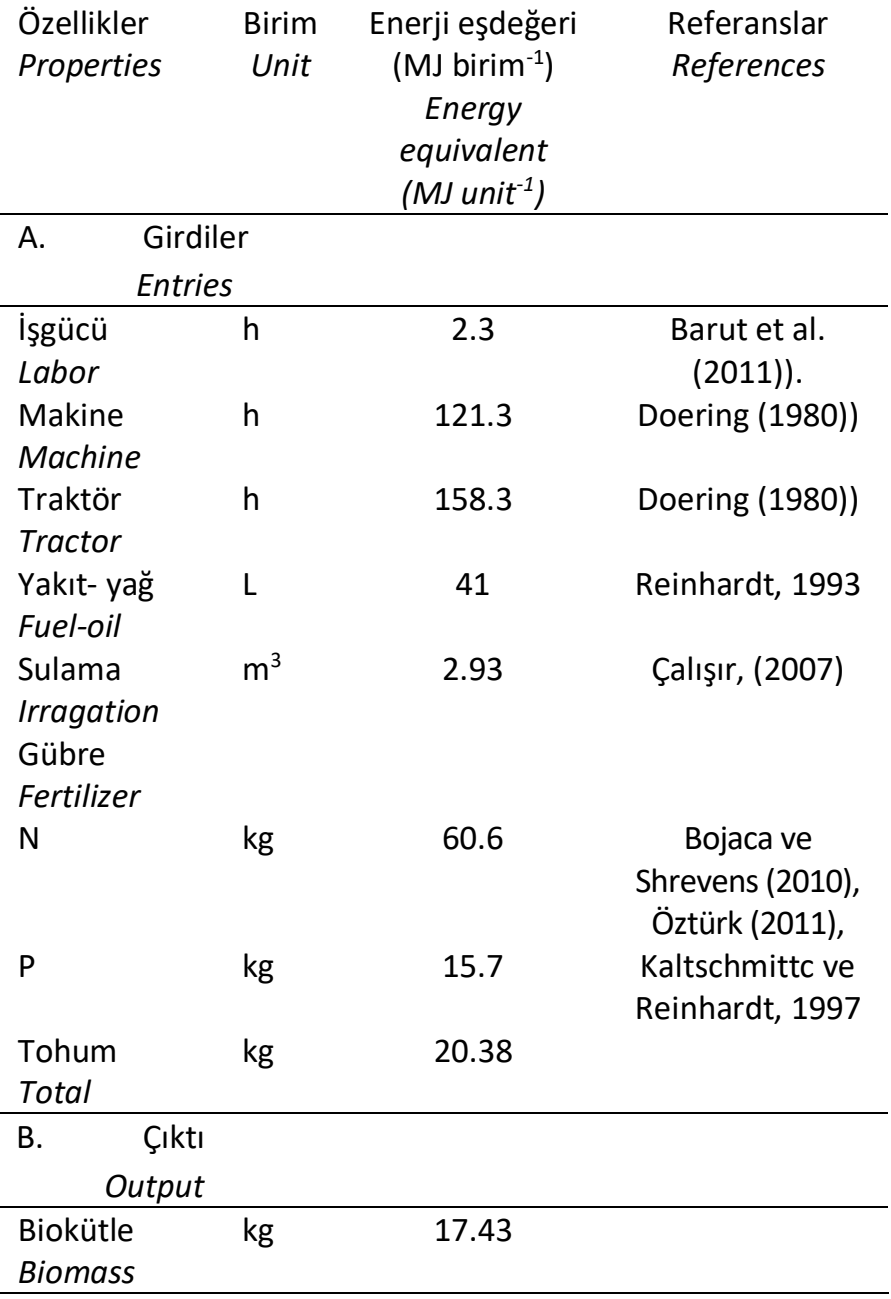

Enerji girdisi direkt enerji, indirekt enerji, yenilenebilir enerji ve yenilenemeyen enerji 
olarak dört grub altında incelenmiş (Karaağaç ve ark. 2011; Acaroğlu, 2006) (Çizelge 7) ve enerji parametreleri ve hesaplamaları Çizelge $8^{\prime}$ de verilmiştir.

Çizelge 7. Enerji grubları (Baran ve ark., 2019)

Table 7. Energy groups (Baran et al., 2019

\begin{tabular}{llc}
\hline Doğrudan Enerji & Insan işgücü ve yakıt enerjisi, & $\mathrm{MJ}$ \\
Direct Energy & sulama & $\mathrm{ha}^{-1}$ \\
Dolaylı Enerji & Gübreleme, tohum ve makine & $\mathrm{MJ}$ \\
Indirect Energy & gücü, traktör gücü & $\mathrm{ha}^{-1}$ \\
Yenilenebilir Enerji & İnsan işgücü, tohum, sulama & $\mathrm{MJ}$ \\
$\begin{array}{l}\text { Renewable energy } \\
\text { Yenilenemeyen }\end{array}$ & Yakıt, gübreleme, makine & $\mathrm{ha}$ \\
Enerji & gücü, traktör, & $\mathrm{MJ}^{-1}$ \\
Non-Renewable & & $\mathrm{ha}^{-1}$ \\
Energy & & \\
\hline
\end{tabular}

Çizelge 8. Enerji Parametreleri (Tabata baeefar, et al., 2009; Zangeneh, et al., 2010; Mousavi-Avval et al., 2011; Öztürk, 2011)

Table 8. Energy Parameters (Tabata baeefar, et al., 2009; Zangeneh, et al., 2010; Mousavi-Avval et al., 2011; Öztürk, 2011)

\begin{tabular}{|c|c|c|}
\hline $\begin{array}{l}\text { Parametreler } \\
\text { Parameters }\end{array}$ & $\begin{array}{l}\text { Birim } \\
\text { Unit }\end{array}$ & $\begin{array}{l}\text { Tanımlamalar } \\
\text { Definitions }\end{array}$ \\
\hline Toplam enerji girdisi & $\mathrm{MJ}$ & $\mathrm{El}$ \\
\hline Total energy input & ha-1 & \\
\hline $\begin{array}{l}\text { Toplam enerji çıktısı } \\
\text { Total energy output }\end{array}$ & $\begin{array}{l}\text { MJ } \\
\text { ha }^{-1}\end{array}$ & EO \\
\hline $\begin{array}{l}\text { Net enerji verimi } \\
\text { Net energy } \\
\text { efficiency }\end{array}$ & $\begin{array}{l}\text { MJ } \\
\text { ha }^{-1}\end{array}$ & EO -EI \\
\hline $\begin{array}{l}\text { Enerji oranı } \\
\text { Energy rate }\end{array}$ & $\%$ & $\mathrm{EO} / \mathrm{EI}$ \\
\hline $\begin{array}{l}\text { Net enerji oranı } \\
\text { Net energy rate }\end{array}$ & $\%$ & $\begin{array}{l}\text { Net enerji verimi / Toplam } \\
\text { enerji girdisi }\end{array}$ \\
\hline $\begin{array}{l}\text { Enerji verimliliği } \\
\text { Energy efficiency }\end{array}$ & $\begin{array}{l}\mathrm{kg} \\
\mathrm{MJ}^{-1}\end{array}$ & $\begin{array}{l}\text { Biokütle verimi / Toplam } \\
\text { enerji girdisi }\end{array}$ \\
\hline $\begin{array}{l}\text { Özgül Enerji } \\
\text { Specific Energy }\end{array}$ & $\begin{array}{l}\mathrm{MJ} \\
\mathrm{kg}^{-1}\end{array}$ & $\begin{array}{l}\text { Toplam enerji girdisi / } \\
\text { Biokütle verimi }\end{array}$ \\
\hline
\end{tabular}

\section{Araştırma Bulguları ve Sonuçlar}

Yapılan hasat işlemlerinden sonra elde edilen yeşil ot ve kuru ot miktarları ile ilgili verim değerleri Çizelge 9. de verilmiştir. Yapılan hasat işlemlerinin ardından toplamda dekardan $2081 \mathrm{~kg}$ yeşil ot verimi ve $468 \mathrm{~kg} / \mathrm{da}$ da kuru ot verimi alınmıştır. Verim değerlerinde ilk biçim den sonra ciddi düşüş görülmüştür. Kesiktaş, (2010) En yüksek kuru ot veriminin yılda 2 biçimden alındığını belirtmiştir.

Çizelge 9. İtalyan çimine ait her bir biçim için ve toplam yeşil ot ve kuru ot verimleri

Table 9. Total green grass and dry grass yields for each form of Italian grass

\begin{tabular}{lcc}
\hline $\begin{array}{l}\text { Biçim sayısı } \\
\text { Number of } \\
\text { mowers }\end{array}$ & $\begin{array}{c}\text { Toplam yeşil ot verimi } \\
\mathrm{kg} \mathrm{da}^{-1} \\
\text { Total green grass } \\
\text { yield }\end{array}$ & $\begin{array}{c}\text { Toplam kuru ot verimi } \\
\mathrm{kg} \mathrm{da}^{-1}\end{array}$ \\
\hline $\begin{array}{l}\text { 1.Biçim } \\
\text { Total dry herb yield }\end{array}$ \\
$\begin{array}{l}\text { 1. Shearing } \\
\begin{array}{l}\text { Biçim } \\
\text { 2. Shearing } \\
\text { 3. Biçim }\end{array}\end{array}$ & 880 & 198 \\
$\begin{array}{l}\text { 3. Shearing } \\
\text { Toplam } \\
\text { Total }\end{array}$ & 817 & 184 \\
\hline
\end{tabular}

Çizelge 9' da görüldüğü üzere araştırma sonucunda toplam yeşil ot verimi $2081 \mathrm{~kg} / \mathrm{da}$, toplam kuru ot verimi ise $468 \mathrm{~kg} \mathrm{da}^{-1}$ olarak bulunmuştur. Karakurt ve Ekiz (1991) kuru ot verimini $418.50 \mathrm{~kg} \mathrm{da}^{-1}$, Akgül (2001) $383.6 \mathrm{~kg} \mathrm{da}$ ${ }^{1}$, Pişkin (2007) ise, en yüksek yeşil ot verimini 6.5 kg da-1 tohum normunda $1543 \mathrm{~kg} \mathrm{da}^{-1}$ olarak bulmuşlardır.

Denemede kullanılan makine ve ekipmanlara ait yakıt tüketimi değerleri Şekil 1' de verilmiştir.

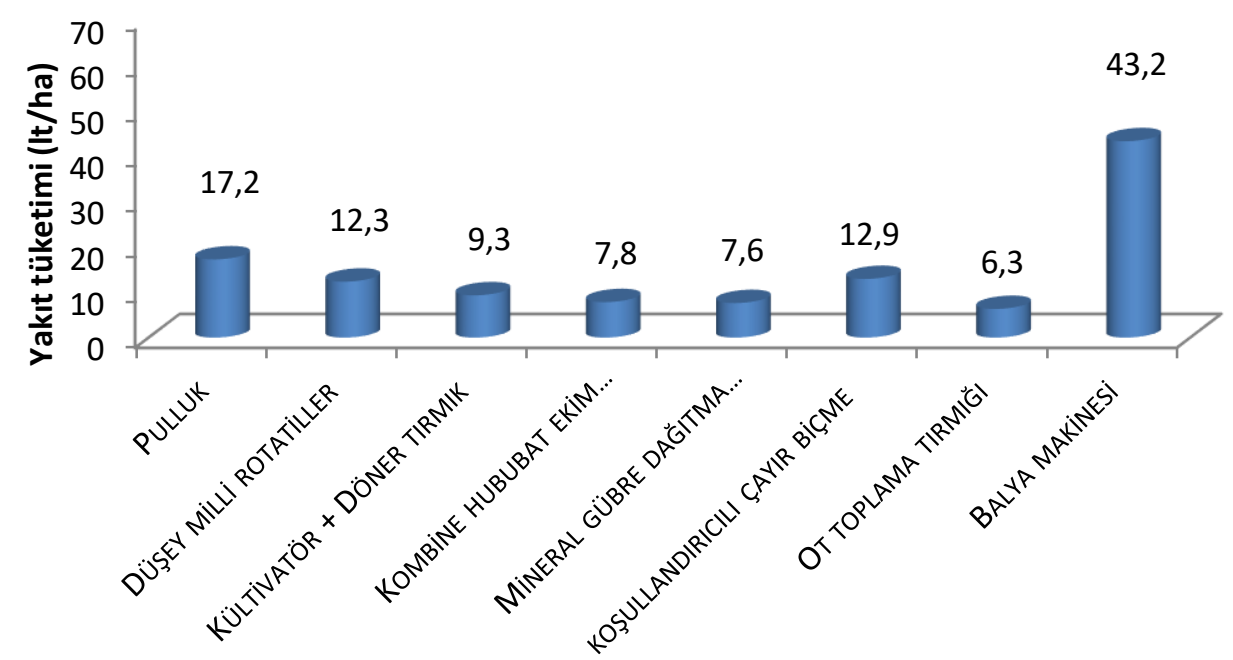

Şekil 1. Kullanılan makinelere ait bazı yakıt tüketimi değerleri Figure 1. Some fuel consumption values of the machines used 
Çalışmada italyan çimi üretiminde toplam yakıt tüketimi 116.6 I ha-1 olarak hesaplanmıştır. Altuntaş ve ark., (2018) silajlık mısır üretimi için toplam yakıt tüketimini geleneksel toprak işleme ile düze ekimde toplamda 120.28 I ha-1, yine geleneksel toprak işleme ile sırta ekim yönteminde ise toplam da 130.75 | ha-1 olarak belirlemişlerdir.

Kullanılan makine grubları arasında toplam yakıt tüketimi içindeki en fazla oranın \%53.52 hasat işlemleri makine grubuna ait olduğu (Balya + Ottoplama tırmığı + Koşullandırıcılı çayır biçme makinesi), bunu \%33.28 oranla toprak işleme makine grubunun (Pulluk+Düşey milli toprak frezesi+ Kültivatör-döner tırmık) takip ettiği, ekim gübreleme makine (Ekim makinesi + Mineral gübre dağıtma makinesi) grubunun ise \%13.20 olduğu tespit edilmiştir. En fazla yakıt tüketimi hasat grubu makinelerde 43.2 I ha-1 ile balya makinesinde, toprak işleme grubu makinelerinde ise 17.2 I ha-1 yakıt tüketimi ile pullukta bulunmuştur. Hasat grubu makinelerinin üç biçim içinde üç defa kullanılması yakıt tüketimlerinin toplam da fazla çıkmasına neden olmuştur. Aynı şekilde mineral gübre dağıtma makinesinin de birim alanda yakıt tüketiminin fazla çıkması ilk iki biçimden sonra ayrı ayrı gübreleme için kullanılmasından kaynaklanmaktadır.

Enerji çıktısı olarak sadece biyokütle elde edilmiştir.

Enerji girdileri için de en fazla \%47.28 ile gübre girdisi bulunmuş, bunu sırasıyla \%31.55 ve \%13.98 ile sulama ve yakıt-yağ girdileri takip etmiştir. (Şekil 2.) Altuntaş ve ark.,(2018)Toplam enerji girdisi içerisindeki kimyasal gübre enerjisinin payı geleneksel düz ekim ve geleneksel sırta ekim sistemleri için sırasıyla \%63.47, \%62.23 olarak belirlemişler ve girdiler içerisinde en yüksek paya sahip olduklarını ifade etmişlerdir.

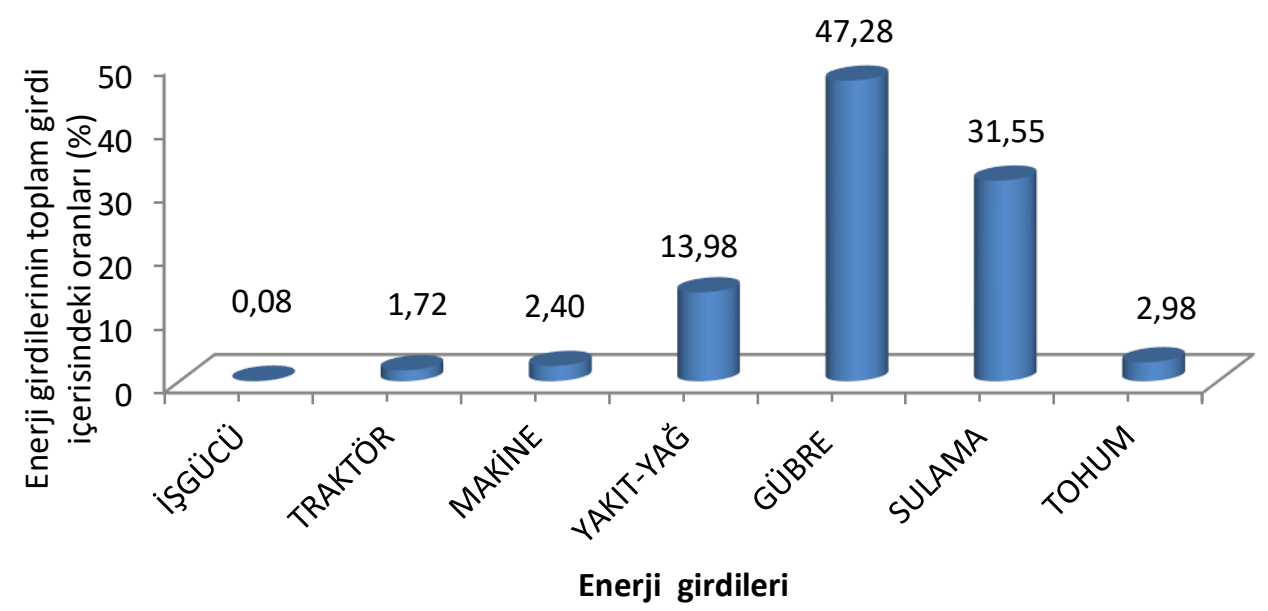

Şekil 2. Enerji girdilerinin toplam girdi içerisindeki oranları Figure 2. The ratios of energy inputs in total input

Toplam enerji çıktısı $81572.40 \mathrm{MJ} \mathrm{ha}^{-1}$ ve toplam enerji girdisi $34197.97 \mathrm{MJ} \mathrm{ha}^{-1}$ olarak hesaplanmıştır (Çizelge 10) ve bunlara bağlı olarak net enerji verimliliği 47374.43 $\mathrm{MJ} \mathrm{ha}^{-1}$ ve enerji oranı 2.39, enerji verimliliğide $0.14 \mathrm{~kg} \mathrm{MJ}^{-1}$ olarak bulunmuştur. Özgül enerji olarak tanımlanan bir kg ürünün elde edilmesi için gerekli enerji miktarıda $7.31 \mathrm{MJ} \mathrm{kg}^{-1}$ olarak hesaplanmıştır. Net enerji veriminin toplam enerji girdisine oranını ifade eden net enerji oranıda 0.58 olarak hesaplanmıştır (Çizelge 11). Houshyar ve ark., (2015) Yaklaşık 73.000 kg ha $^{-1}$ silajlık mısır üretmek için $55.000 \mathrm{MJ}$ ha $^{-1}$ enerji kullanıldığını ve ayrıca gübre, sulama, dizel yakıt ve tohum enerji girdilerinin toplam enerji girdisi içerisindeki paylarını sırasıyla\% 65, \% 13, \% 12 ve $\% 5$ olarak belirtmişlerdir. 
Çizelge 10. Enerji bilançosu Table 10. Energy balance

\begin{tabular}{|c|c|c|}
\hline A.Girdiler & Mj ha $^{-1}$ & $\%$ \\
\hline $\begin{array}{l}\text { İşgücü } \\
\text { Labor }\end{array}$ & 28.59 & 0.08 \\
\hline $\begin{array}{l}\text { Traktör } \\
\text { Tractor }\end{array}$ & 586.83 & 1.72 \\
\hline $\begin{array}{l}\text { Makine } \\
\text { Machine }\end{array}$ & 822.15 & 2.40 \\
\hline $\begin{array}{l}\text { Yakıt-yăg } \\
\text { Fuel }\end{array}$ & 4780.60 & 13.98 \\
\hline $\begin{array}{l}\text { Gübre } \\
\text { Fertilizer }\end{array}$ & 16170.20 & 47.28 \\
\hline $\begin{array}{l}\text { Sulama } \\
\text { Irragation }\end{array}$ & 10790.60 & 31.55 \\
\hline $\begin{array}{l}\text { Tohum } \\
\text { Seed }\end{array}$ & 1019.00 & 2.98 \\
\hline $\begin{array}{l}\text { Toplam Girdi } \\
\text { Total Input }\end{array}$ & 34197.97 & 100 \\
\hline $\begin{array}{l}\text { B.Çıktı } \\
\text { Output }\end{array}$ & & \\
\hline $\begin{array}{l}\text { Biyokütle Verimi } \\
\text { Biomass Yield }\end{array}$ & 81572.40 & \\
\hline
\end{tabular}

Çizelge 11. Enerji değerlendirme parametreleri Table 11. Energy evaluation parameters

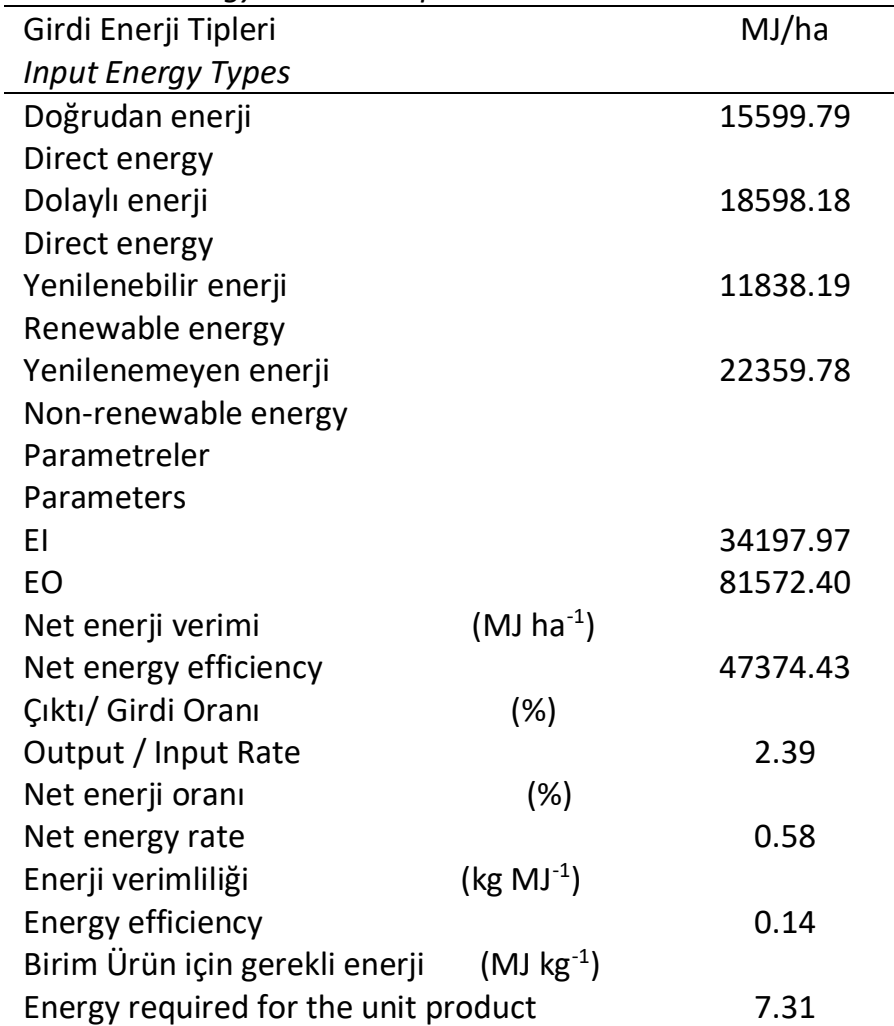

Enerji girdisi doğrudan enerji, dolaylı enerji, yenilenebilir enerji ve yenilenemeyen enerji olarak dört grub altında incelenmiş (Şekil 3).

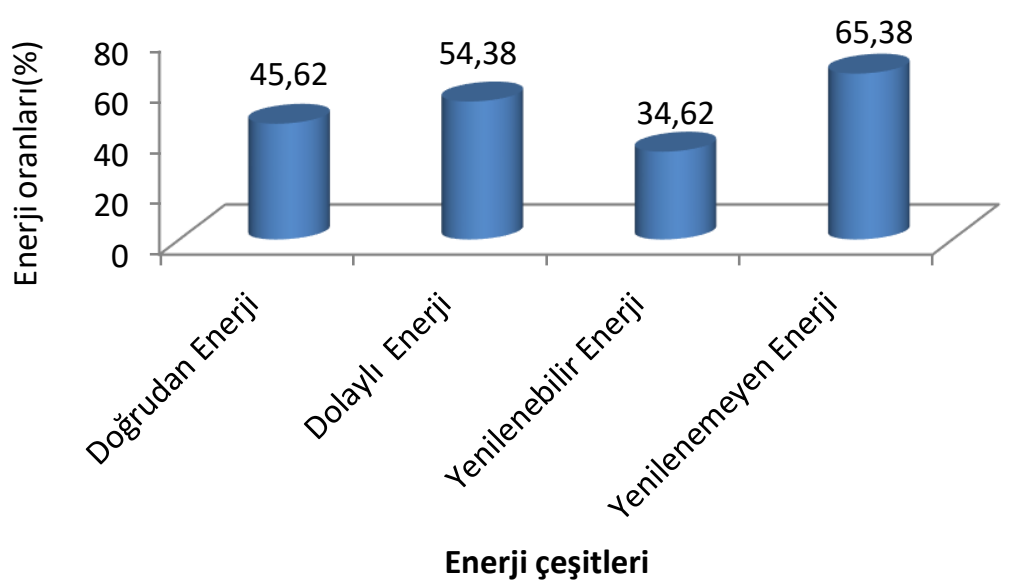

Şekil 3. Enerji oranları

Figure 3. Energy rates

İtalyan çimi yetiştiriciliğinde doğrudan, dolaylı, yenilenebilir ve yenilenemez enerji oranları sırasıyla \%45.62, \%54.38, \%34.62 ve \%65.38 olarak hesaplanmıştır. Komleh ve ark., (2011) İranın Karaj şehrinde silajlık mısır yetiştiriciliğinde enerji kullanımı üzerine yaptıkları araştırmada doğrudan enerjinin payı \%25, dolaylı enerjinin payını ise $\% 75$ ve toplam enerji girdisini ve enerji çıktısını sırasıyla 68.928 ve $148.380 \mathrm{MJ}$ ha ${ }^{-1}$ olarak hesaplamışlardır.
Mobtaker ve ark., (2012), elektrik, kimyasal gübreler ve diğer önemli girdilerin optimum tüketimleri, yalnızca çevreye olumsuz etkilerin azaltılmasında değil, aynı zamanda sürdürülebilirliğin korunmasında da faydalı olacağını. Toprak analizinin yapılmaması, kimyasal gübrenin bilinçsiz kullanımına yol açtığını. Elektrik tüketimini azaltmak için modern sulama yöntemlerinin yüksek verimlilikle (Su tüketiminden tasarruf edilmesini sağlar.) 
kullanılmasının önerilebileceğini. Ayrıca bitki, toprak ve iklim kirliliği gibi enerji girdilerinin olumsuz etkilerini azaltmak için yeni politikaların uygulanması gerektiğini. Bu nedenle, enerji tüketiminin analizinin önemli bir görev olduğunu belirtmiştir.

Yoncada değişik gelişme dönemlerinde yapılan ham protein analizlerinde, vejetatif gelişmenin hızlı olduğu dönemde protein oranının yüksek, olgunluğun ilerleyen dönemlerinde ise belirgin bir şekilde düştüğünü ve araştırma süresince biçim sayısı ve zamanına bakıldığı zaman da ham protein içeriğinin çiçeklenme başlangıcında \%16.81 - 19.34 tam çiçeklenme döneminde \%13.45 - 15.74 ve meyve bağlama döneminde ise \%9.71 - 11.53 arasında değişim gösterdiği görülmüştür. (Ünalp, 2014).

Bernard ve ark (2002), mısır silajı yerine farklı oranlarda İtalyan çim silajı kullanmanın sağım dönemindeki ineklerde kuru madde tüketiminde değişiklik oluşturmadığını, ancak NDF ve ADF tüketimlerinin yükseldiğini, süt, süt yağı ve protein veriminin arttığını, ancak canlı ağırlık ve vücut kondüsyon puanında farklılık kaydedilmediğini belirlemişler, dolayısıyla mısır silajının yerine ya da kısmen kullanılarak rasyonda çim silajı kullanılabileceğini bildirmiştir.

Ülkemizde ki yem bitkileri tarımının gelişmesi için mevcut ekim alanlarının içindeki yem bitkileri ekim alanlarının oranının arttırıması gereklidir. Bunun yanı sıra ülkemizde nadasa bırakılan arazi yaklaşık 3.697.000 hektarlık bir alanda nadas uygulaması yapılmaktadır. Özellikle İtalyan çimi gibi tek ya da iki yıllık yem bitkileri ekim nöbetinde kullanılabilir. Her ölçekteki büyükbaş ve küçükbaş hayvan yetiştiricileri ile yem bitkisi yetiştiricileri italyan çimi yetiştiriciliğine teşvik edilmeli ve bu teşviklerin sonuç vermesi için yem bitkileri yetiştiriciliğinin desteklenmesi gereklidir. Unutmamalı ki yem bitkileri yetişticiliği ile hayvancılık birbirini etkileyen iki önemli faktördür. Yem bitkilerinin çeşitliliğini artırmak için İtalyan çimi önemli bitkidir. İtalyan çimi çeşitlerinin ülkemizin iklim özelliklerine uygunluluğunu göz önünde bulundurursak, hayvancılık için önemli besin maddeleri bakımından zengin, yüksek ürün kapasiteli İtalyan çimi çeşitlerinin yetiştirilmesinin yaygınlaştırılması ülkemizdeki kaba yem sorunununun giderilmesini sağlayabilir (Özkul ve ark., 2012).

İtalyan çimi üretiminde mevcut işletmeler için de herhangi bir ek makine parkına ihtiyaç duyulmadan, hububat ya da yonca üretimi gerçekleştirilmesinde kullanılan tarım alet ve makinelerin kullanılabilir olması yatırım maliyetinin olmamasını sağlamaktadır. Bu bakımdan sonuç olarak, kaba yem üretiminde alışılagelmiş yem bitkilerinin üretimine ve ekim nöbetine alternatif olarak çiftçilerimizin İtalyan çimi üretimine teşvik edilmesinin yem bitkileri yetştiriciliği açısından faydalı olacağı kanaatindeyiz.

\section{Çıkar Çatışması Beyanı: Makale yazarları} aralarında herhangi bir çıkar çatışması olmadığını beyan ederler.

\section{KAYNAKLAR}

Acaroğlu, M. (2006). Katı ve Sıvı Biyokütle (Biyodizel) Üretiminde Enerji Bilançolarının Karşılaştırılması. Tarımsal Mekanizasyon 23. Ulusal Kongresi, 6-8 Eylül 2006, Çanakkale syf : 103-108

Açıkgöz, E. (2001). Yem bitkileri. Uludağ Üniversitesi Güçlendirme Vakfı Yayınları 182, ViPAŞ Yayın No.58, Bursa, 180-187.

Akgül, F. (2001). Ankara şartlarında farklı sıra aralığı ile ekim ve azotla gübrelemenin tek yıllık çim (Lolium multiflorum Lam.)'in ot verimi ve kalitesine etkileri. Yüksek lisans tezi (basılmamış). Çanakkale On Sekiz Mart Üniversitesi Fen Bilimleri Enstitüsü. Tarla Bitkileri Anabilim Dalı. Çanakkale.

Alçiçek, A. (1988). İkinci Ürün ve Artıklarının Yem Değerleri Üzerine Araştırmalar. Ege Üniversitesi, Fen Bilimleri Enstitüsü, Zootekni Anabilim Dalı, Yüksek Lisans Tezi, s. 81, İzmir.

Alçiçek, A., Tarhan, F., Özkan, K., Adışen, F. (1999). İzmir İli ve Civarında Bazı Süt Sığırcılığı İşletmelerinde Yapılan Silo Yemlerinin Besin Madde İçeriği ve Silaj Kalitesinin Saptanması Üzerine Bir Araştırma. Hayvansal Üretim, 39-40: 54-63.

Alçiçek, A. (2002). Süt Sığırı Rasyonu Yapımında Temel ilkeler. Ege Tarımsal Araştırma Enstitüsü Müdürlüğü Yayınları, No: 106:124-135.

Altuntaş, E., Özgöz, E., Dede,S., (2018). Orta Karadeniz Geçit İklim Kuşağında Silajlık Mısır Üretiminde Toprak İşle-menin Enerji Kullanım Etkinliğine Etkisi. Selcuk Journal of Agriculture Food Science, (2018) 32 (3), 238-248

Anonim (1998). Hayvancılık Kongresi. 4-5 Kasım 1998, Tarım ve Köy İşleri Bakanlığı Yayınları, s:9-96 
Anonim,

(2020a).

http://www.tuik.gov.tr/PreTablo.do?alt_id=1001 Erişim tarihi 09.03.2020

Anonim,

(2020b).

http://www.tuik.gov.tr/UstMenu.do?metod=temelis t Erişim tarihi 09.03.2020

Anonim,

https://www.tareks.com.tr/_tohumculuk/index.php? ac $=004$ yonca Erişim tarihi 24.02.2020

Anonymous, (2008). FAO Statistical Yearbook.

Baran, M. F., Karaağaç, H. A., Bolat, A., Çil, A. \& Çil, A. N. (2019). Yerfıstığı Üretiminde Enerji Kullanım Etkinliğinin Belirlenmesi (Adana ili örneği). Avrupa Bilim ve Teknoloji Dergisi, (15), 103-111.

Barut, Z. B., Ertekin, C., Karaağaç, H. A. (2011). Tillage Effects on Energy Use for Corn Silage in Mediterranean Coastal of Turkey. Energy 36(9):5466-5475.

Baytekin, H., Kızılşimşek, M. ve Demiroğlu, G. (2009). Çim ve Ayrık Türleri s. 561-572. Editör: R. Avcıpğlu, R. Hatipoğlu, Y. Karadağ. Yem Bitkileri Genel Bölüm Cilt III. Tarım ve Köyişleri Bakanlığı Tarımsal Üretim ve Geliştirme Genel Müdürlüğü, İzmir.

Bernard, J. K., West, J. W., Trammell, S. (2002). Effect of replacing corn silage with annual ryegrass silage on nutrient digestibility, intake, and milk yield for lactating dairy cows. J. Dairy Sci. 85(9): 2277-2282.

Bojoca, C. R., Schrevens, E. (2010). Energy assessment of peri-urban horticulture and its uncertainty: case study for Bogota, Colombia. Energy; 35:2019-18

Çalışır, S. (2007). The evaluation of performance and energy usage in submersible deep well irrigation pumping plants. Agricultural Mechanization in Asia, Africa, and Latin Amerika (AMA). Vol. 38 No.1 s. 9-17.

Darvıshı, A. (2009). Bazı tek yıllık çim (Lolium multiflorum L.) çeşitlerinin morfolojik özellikleri ve yem verimleri. Yüksek Lisans Tezi (basılmamış). Ankara Üniversitesi, Fen Bilimleri Enstitüsü, Tarla Bitkileri Anabilim Dalı, Ankara.

Doering, O. C. (1980). Accounting for energy in farm machinery and buildings. In:Pimentel David, editor. Handbook of Energy Utilization in Agriculture.FL, USA: CRC Press, Inc, ISBN 0-8493-2661-3;. p. 9-14.

Erdal, G., Esengün, K., Erdal, H. and Gündüz, O. (2007). Energy Use And Economical Analysis of sugar Beet Production in Tokat Province of Turkey. Energy, 32: 35-41

Houshyar, E., Zareifard, H. R., Grundmann, P., Smith, P. (2015). Determining efficiency of energy input for silage corn production: An econometric approach. Energy 93 (2015) 2166-2174

Kaltschmitt, M., Reinhardt, G. A. (1997). Nachwachsende Energieträger - Grundlagen, Verfahren, ökologische Bilanzierung, Braunschweig.

Karaağaç, M. A., Aykanat, S., Çakır, B., Eren, Ö., Bereket, B. Z., Turgut, M. M., et al., (2011). "Energy balance of wheat and maize crops production in Haciali undertaking", 11th International Congress on Mechanization and Energy in Agriculture Congress, iSTANBUL, TÜRKIYE, 21 Eylül - 23 Ocak 2011, pp.1-10

Karakurt, E. ve Ekiz, H. (1991). İskenderiye üçgülü (Trifolium alexandrinum L.) ile İtalyan çimi (Lolium multiflorum Lam.) karışım oranlarının ot verimine etkisi. Ankara Üniversitesi Ziraat Fakültesi Dergisi, 1999, Vol. 44, No
1-2, s. 97-104. Ankara.

Karayiğit, ì. (2005). Farklı Olgunluk Dönemlerindeki Bazı Melez Mısır (Zea Mays L.) Çeşitlerinin silaj Kaliteleri Üzerine Araştırmalar. Kahramanmaraş Sütçü İmam Üniversitesi Fen Bilimleri Enstitüsü Tarla Bitkileri Anabilimdalı, Yüksek Lisans Tezi, sayfa :36, Kahramanmaraş.

Kesiktaş, M., (2010). Karaman'da Farklı Ekim Zamanları Ve Azotlu Gübre Dozu Uygulamalarının İtalyan Çiminin ( Lolium Multiflorum Westerwoldicum Caramba ) Yem Verimine Etkileri

Komleh, S. H. P., Keyhani, A., Rafiee, Sh., Sefeedpary, P. (2011). Energy use and economic analysis of corn silage production under three cultivated area levels in Tehran province of Iran . Energy 36 (2011) 3335 3341

Kuşvuran, A. ve Tansı, V. (2004). Çukurova koşullarında farklı sıra aralıklarının tek yıllık çim (Lolium multiflorum cv. caramba)'in ot ve tohum verimine etkisi üzerine bir araştırma. Çukurova Üniversitesi Bilimsel Araştırma Projeleri Birimi ZF/2002/BAP/72 Nolu Proje Sonuç Raporu, Kasım, 2004,Adana.53 s.

Kuşvuran, A., Tansı, V. (2005). Çukurova koşullarında farklı biçim sayısı ve azot dozunun tek yıllık çimin (Lolium multiflorum cv. Caramba) ot ve tohum verimine etkisinin saptanması. Türkiye VI. Tarla Bitkileri Kongresi, 5-9 Eylül 2005, Antalya Cilt II, Sayfa 797802.

Kuşvuran, A., Kaplan, M. ve Nazlı, R. İ. (2014). Effects of ratio and row spacing in hungarian vetch (Vicia pannonica Crantz.) and annual ryegrass (Lolium multiflorum Lam.) intercropping system on yield and quqlity under semiarid climate conditions. Turkish Journal of Field Crops. 19 (1) 118-128.

Lenuweit, U., Gharadjedaghi, B. (2002). Biologische basisdaten zu Lolium perene, Lolium multiflorum, Festuca pratensis und Trifolium repens. Gesellschaft für Freilandökologie und Naturschutzplanung $\mathrm{mbH}$, Bayreuth.

Mc Cormick, M. E., Cuomo, G. J., Blouin, D. C. (1998). Annual ryegrass stored as balage, haylage or hay for lactating dairy cows. J. of Prod. Agric. 11(3): 293-300.

Mobtaker, H. G., Akram, A., Keyhani, A. (2012). Energy use and sensitivity analysis of energy inputs for alfalfa production in Iran. Energy for Sustainable Development 16 (2012) 84-89

Mousavi-Avval, S. H., Rafiee, S., Jafari, A., Mohammadi, A. (2011). Optimization of energy consumption for soybean production using Data Envelopment Analysis (DEA) approach. Applied Energy, 35, 2156- 2164

Ohshima, M., Nagatomo, T., Kubota, H., Tano, H., Okajima, T., Kayama, R. (1988). Comparison of nutritive values between hays and silages prepared from Italian ryegrass (Lolium multiflorum Lam.) and its pres cake using goats. J. Japan. Grassl. Sci. 33(4): 396-401.

Özkan, U., ve Demirbağ, N. Ş. (2016). Türkiyede Kaliteli Kaba Yem Kaynaklarını Mevcut Durumu. Türk Bilimsel Derlemeler Dergisi 9 (1): 23-27.

Özkul, H., Kırkpınar, F., Tan, K. (2012). Ruminant Beslemede Karamba (Lolium Multiflorum cv. Caramba) Otunun Kullanımı. Ege Üniversitesi Ziraat Fakültesi Zootekni Bölümü Yemler ve Hayvan Besleme Anabilim Dalı, Bornova, İzmir 
Öztürk, H. H. (2011). Bitkisel Üretimde Enerji Yönetimi. Hasad Yayıncılık Ltd.Şti. ISBN: 978-975-8377-78-7

Öztürk, Ö., Ada, R., Akınerdem, F. (2009). Bazı Aspir Çeşitlerinin Sulu Ve Kuru Koşullarda Verim Ve Verim Unsurlarının Belirlenmesi. Selçuk Üniversitesi, Selçuk Tarım ve Gıda Bilimleri Dergisi, 23 (50): 16-27

Parlak, E. L. (2005). Çukurova Koşullarında Bakla (Vicia faba L.)'nın Arpa (Hordeum vulgare L.), Tritikale (Triticale), Buğday (Triticum aestivum L.) ve Tek Yıllık Çim (Lolium multiflorum Lam.) ile Karışımlarının Biomas Üretim Kapasitelerinin Saptanması Üzerine Bir Araştırma. Yüksek Lisans Tezi, Ç.Ü. Fen Bilimleri Enstitüsü Tarla Bitkileri A.B.D., Adana, 2005.

Pişkin, M. (2007). "Italyan Çiminde (Lolium Multiflorum Lam.) Farklı Tohum Miktarlarının Verim Ve Bazı Verim Unsurları Üzerine Etkileri " Selçuk Üniversitesi Fen Bilimleri Enstitüsü Tarla Bitkileri Anabilim Dalı Yüksek Lisans Tezi, 2007 Konya

Reinhardt, G. A. (1993). Energie und $\mathrm{CO}_{2}$ Bilanzierung nachwchsender Rohdtoffe. 2nd. Edition Vieweg, Braunschweig/Wiesbaden

Sayar, M., Anlarsal, M., Basbağ, M.(2010). Güneydoğu Anadolu Bölgesinde Yem Bitkileri Tarımının Mevcut Durumu Sorunları Ve Çözüm Önerileri. Harran Üniversitesi. Harran Tarım ve Gıda Bilimleri Dergisi, 14 (2): 59-67.

Schota, H. A., Veıhıng, R. M. (1951). The ryegrass. Forages,
Chapter;28, 336-340.

Serin, Y., Tan, M. ve Şeker, H. (1996). Azotla gübreleme ve ekim oranının tek yılık çim(Lolium multiflorum Lam.)'de ot ve ham protein verimi ile otun ham protein oranına etkileri. Türkiye 3. Çayır Mera ve Yem Bitkileri Kongresi (17-19 Haziran 1996), Erzurum. 732-738.

Soya, H., Avcıoğlu, R.ve Geren, H. (2004). Yem Bitkileri. Hasad Yayıncılık, 223 s.

Tabatabaeefar, A., Emamzadeh, H., Varnamkhasti, M. G., Rahimizadeh, R., Karimi, M. (2009). Comparison of energy of tillage systems in wheat production. Energy, 34, 41-45.

Ünalp, E. (2014).Farklı Gelişme Dönemleri Ve Biçim Sıralarında Yonca (Medicago Sativa L.) Kuru Otunun Ham Protein, Selüloz Ve Bazı Mikrobiyolojik Özelliklerinin Belirlenmesi.Namık Kemal Üniversitesi Fen Bilimleri Enstitüsi Yüksek Lisans Tezi. 2014 Tekirdağ

Yaldiz, O., Ozturk, H. H., Zeren, Y., Bascetincelik. A. (1990). Energy use in field cropproduction in Turkey. Journal of Agriculture Faculty University Akdeniz1990b;3:51e62 [In Turkish].

Zangeneh, M., Omid, M., Akram, A. A. (2010). Compara-tive study on energy use and cost analysis of potato production under different farming technologies in Hamadan province of Iran. Energy, 35, 2927-2933. 